\title{
Mechanised Harvesting of Broadleaved Tree Species in Europe
}

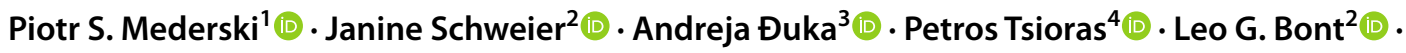 \\ Mariusz Bembenek ${ }^{1}$ (1)
}

Accepted: 9 December 2021 / Published online: 24 January 2022

(c) The Author(s) 2022

\begin{abstract}
Purpose of the Review The application of cut-to-length (CTL) technology for harvesting and processing timber from broadleaved tree species is a challenging process, due to thick branches, stem sweep, forks and high wood density. The objective of this review was to describe the current state of harvester use and characterise the effectiveness of mechanised forest operations for broadleaved and mixed forest stands in Europe, paying particular attention to productivity and product quality aspects. An additional aim was to identify the greatest difficulties associated with harvesting broadleaved tree species today and to indicate future challenges and areas for improvement.

Recent Findings An interest in wider harvester use for broadleaved tree species started after the storm Lothar in France in 1999. Early experiences demonstrated that lower productivity is common when harvesting broadleaved tree species, due to limitations in delimbing and the high frequency of sweep. Initially, modifications were made to harvester heads, while a newly designed head (CTL $40 \mathrm{HW}$ ) was later developed within a European project in 2005-2007. Using various heads, very high productivity was achieved in some cases, but log recovery was unsatisfactory, with large tree tops left without delimbing. The delimbing was of lower quality and log length inaccuracy was observed, as well as economic losses due to damage to plywood caused by feed rollers. These issues resulted in a change in harvester head construction, including work on a patent for a head designed specifically for harvesting broadleaved tree species.

Summary The harvester heads that have been developed to date for broadleaved tree species have mainly been used within Central Europe, where the high incidence of broadleaved tree species and their particular morphological features (thick branches and sweep) are a major challenge for CTL technology. There have been many research projects related to this issue: in the last 15 years, there were a few larger initiatives leading to the design and development of harvester heads for broadleaved tree species, with participation from institutions and universities in France, Germany and Poland. There are currently no ongoing initiatives, but the formation of new ones is strongly recommended because today's forests have a growing share of broadleaved tree species and are being managed to an increasing extent with CTL technology.
\end{abstract}

Keywords Deciduous tree species $\cdot$ Forest operation $\cdot$ Hardwood $\cdot$ Harvester $\cdot$ Harvester head $\cdot$ Productivity $\cdot$ Thick branch

This article is part of the Topical Collection on Forest Engineering

Piotr S. Mederski

piotr.mederski@up.poznan.pl

$\triangle$ Janine Schweier

janine.schweier@wsl.ch

Andreja Đuka

andreja.duka@sumfak.unizg.hr

Petros Tsioras

ptsioras@for.auth.gr

Leo G. Bont

leo.bont@wsl.ch

Mariusz Bembenek

mariusz.bembenek@up.poznan.pl
1 Department of Forest Utilisation, Faculty of Forestry and Wood Technology, Poznań University of Life Sciences (PULS), ul. Wojska Polskiego 71A, 60-625 Poznań, Poland

2 Swiss Federal Institute for Forest, Snow and Landscape Research (WSL), Zürcherstrasse 111, 8903 Birmensdorf, Switzerland

3 Department of Forest Engineering, Faculty of Forestry and Wood Technology, University of Zagreb, Svetošimunska 25, 10002 Zagreb, Croatia

4 Department of Harvesting and Technology Forest Products, Lab of Forest Utilisation, Aristotle University of Thessaloniki, P.O. Box 227, 54-124 Thessaloniki, Greece 


\section{Introduction}

In contrast to harvester use for forest operations in conifer stands, the use of harvesters in broadleaved forest stands has a relatively short history. This is because harvesting and processing timber from broadleaved species is more difficult than from coniferous tree species e.g. spruce and pine. Thick branches make it difficult to obtain logs from the top parts of trees, and hardwood trees have higher wood density than conifers.

Besides challenges associated with certain tree species, there may be other factors that limit wide harvester use, like the low rate of investment capability and fear of unemployment. However, today's market conditions, with low availability of manpower, may accelerate wider use of cutting-edge harvesting technology.

One of the first records of harvester productivity in broadleaved forest stands was with the harvester type Sifor 614 in France in 1993-1996 [1, 2], where European beech (Fagus sylvatica L.), oak (Quercus sp.), European hornbeam (Carpinus betulus L.), chestnut (Castanea sativa Mill.), birch (Betula sp.) and aspen (Populus sp.) were harvested. Early use of harvesters was also recorded in the 1990s, in Finland (birch) and in Spain (Eucalyptus sp.) [3, 4, 5]. Basically, the use of harvesters for broadleaved species was rather sporadic at the end of the twentieth century. This changed after wind damage resulting from the storm Lothar in 1999, when large areas needed clearing and harvesters were a suitable option in comparison to low-safety motor-manual salvage removal [6]. The need for wider harvester use led to head modifications to make timber processing more effective and with satisfactory productivity [2].

Bigot and Cuchet [7] conducted a large study of harvester head usability in broadleaved forest stands in France and tested 40 harvesters with heads originally dedicated to coniferous species and some adapted for broadleaved tree species. Compared to use with coniferous species, lower productivity was observed and more frequent repairs were needed with broadleaved tree species, which is still true today. In 2004-2005, studies were carried out on harvester use in coppice chestnut forest stands, and later research considered beech and eucalyptus forest stands in Europe and North America [8, 9, 10]. Further studies focused on harvester use in poplar short-rotation plantations [11, 12], as well as on improved productivity during multi-stem processing of spruce and birch [13]. Lower quality wood produced during delimbing, as well as bark shavings, were recognised as useful energy sources. Recently, studies have indicated that trees with thinner branches in younger stands could be processed efficiently with harvesters [14].

Meanwhile, cut-to-length (CTL) technology (defined here as harvester use for processing short logs) for timber harvesting has become more popular in Europe [15]. In general, forest operations carried out by harvesters differ among countries in Europe, with a larger share of CTL technology in North, Central and West Europe in comparison to South and South-East Europe [15, 16, 17, 18••]. One reason for this variation is the tree species composition-coniferous tree species are more suitable for CTL technology and more dominant in North, Central and West Europe [15, 19]. However, Scots pine (Pinus sylvestris L.) and Norway spruce (Picea abies (L.) Karst) are conifers that are recognised as vulnerable to changing climate conditions, and their abundance in Central European lowland forests is expected to decrease significantly with global change [20]. At the same time, broadleaved tree species may find the new conditions more suitable; according to the latest findings and predictions, European beech and pedunculate oak (Quercus robur L.) will become (increasingly) dominant in large parts of Central Europe [20]. Thus, an increasing potential for the use of CTL technology can be expected, taking into account that the interest in manual work has declined recently.

There is a strong need to adapt silvicultural management practices and to provide forest managers with evidencebased recommendations, especially regarding CTL technology $[21 \bullet \bullet, 22 \bullet \bullet]$. Based on initial studies of the available literature, it was hypothesised that development of CTL technology for broadleaved species is an unavoidable step in the expansion of forest operations. Therefore, the objective of this study was to assess the current state of harvester use and characterise the effectiveness of its use for broadleaved tree species in Europe, paying particular attention to economic (productivity) and product quality aspects. An additional objective was to identify challenges with mechanised forest operations in broadleaved or mixed stands and to establish what could or should be improved to enhance the efficiency of the timber harvesting of deciduous trees.

\section{Material and Methods}

An English literature review was conducted in the databases Web of Science, Scopus and Google Scholar in April and May 2021. The following keywords were used to retrieve available studies: hardwood cut-to-length; mechanised harvesting of broadleaves; mechanised harvesting of hardwood species; mechanised forest operations in mixed stands; mechanised forest operations in broadleaved stands; mechanised thinning operations in mixed stands; mechanised thinning operations in broadleaved stands; harvester thinning operation.

In the first step, no specific time span was chosen in order to get a comprehensive basis of relevant studies for the introduction and discussion parts of the article. Titles, abstracts 
and/or keyword fields were read to decide whether each study was related to the topic. In total, 227 studies were identified using Web of Science, another 327 with Scopus and 229 with Google Scholar. After excluding studies that were out of scope, older than 10 years (published before 2011) or double-counted, a total of 51 studies were considered further to review and summarise the current state of CTL harvesting in hardwood stands.

In a second step, national sources were searched, including sources in local languages. These included not only magazines dedicated to practitioners, but also websites (e.g. www.waldw issen.net, which is maintained in German, French, Italian and English) and personal communication between experts and the authors of this study. Specifically, the following magazines were screened: Forsttechnische Information (Germany), Der Waldbauer (Austria), Wald \& Holz (Switzerland), Drwal (Poland), Šumarski list and Nova mehanizacija šumarstva (Croatia) and FCBA reports (France). Finally, international and local research projects, dissertations and reports were searched and considered. Additional sources were also considered based on the expert knowledge of all co-authors.

Results were reported according to their geographical assignment, distinguishing regions in Europe as North, Central-West, Central-East, South-West and South-East, with their respective countries (Table 1) [23]. References were structured according to the region and based on four important aspects related to CTL hardwood harvesting: productivity and cost, product quality (timber assortments), delimbing quality and utilisation of tree stems for timber assortments. However, the sections might differ slightly depending on the regions' characteristics and the relative importance of challenging factors studied in the local conditions.

\section{Results and Discussion}

\section{Overview}

The forest cover and tree species composition of forests in Europe vary across the regions (Table 1). The most forested region is North Europe, which also has the largest share of coniferous tree species. However, the highest growing-stock density is in Central-East Europe. Broadleaved tree species occur in all regions, with South-West Europe having the largest share of forest stands with deciduous tree species (Table 1).

\section{Experiences with Harvesting Broadleaved Tree Species}

\section{North Europe}

In North Europe, about 54\% of the land area is forested $(71.299 \mathrm{mln} \mathrm{ha})$, and this region has the largest share of conifers in Europe (67\%) and the lowest share of broadleaved tree species (16\%), with both forest types usually managed as high forests. Broadleaved tree species, especially of the younger age classes, are most often used for energy purposes $[24,25]$. The average growing-stock density is $129 \mathrm{~m}^{3}$ $\mathrm{ha}^{-1}$ and is stable: in the last 10 years (2010-2020), it has increased by $0.8 \%$ [23].

CTL technology is widely used in North Europe [15, $18 \bullet \bullet$, where strip roads are usually established every $20 \mathrm{~m}$ to make stands accessible for harvesters. However, a larger share of mechanised harvesting is present in Sweden and Finland than in Baltic countries [15, 17]. In the last decade, CTL technology applications in broadleaved forest stands were mostly carried out in Finland and Latvia and focused on birch and alder. In Lithuania, processing with a newly designed harvester head was carried out on birch and aspen [26].

Few studies from Finland were carried out in stands with downy birch (Betula pubescens Ehrh.). One of these studies was focused on the productivity of multi-stem harvesting in thinning and clear-cut stands dominated by young downy birch trees, from which pulpwood and energy wood sections were processed. The Komatsu 901.4 harvester with a Komatsu 350.1 harvester head was used with an option for multi-stem harvesting [25]. Tree-specific time studies were conducted, and productivity models based on these investigations were elaborated for multi-stem cutting. Clear-cutting in older stands resulted in a higher cutting productivity than in younger stands where thinning was carried out. Multi-tree cutting was more productive, but only marginally and in both types of stands. This was due to the small share of multi-stem cutting. Harvesting conditions were more favourable in clear-cutting than in thinning operations. The multi-tree harvesting productivity was from 5.6 to $17.4 \mathrm{~m}^{3} \mathrm{PMH}_{0}^{-1}$ (productive machine hour without delays) in clear-cut stands and from 4.8 to $10.9 \mathrm{~m}^{3} \mathrm{PMH}_{0}{ }^{-1}$ in thinned stands. In terms of multi-tree cutting, the harvester head processed only 1.2 trees per cycle in clear-cut stands and 1.1 trees per cycle in thinning stands. Finally, it was concluded that improving harvesting equipment for multi-tree cutting of birch and other tree species that have stems with sweep is necessary.

In another study from Finland, downy birch harvesting was carried out in young (age 12 to 29 years) forest stands [24]. A Valmet 911.3 harvester was used for cutting with an engine power of $170 \mathrm{~kW}$. The harvester was equipped with the Bracke C16.b accumulating felling head fitted with a circular saw disc. A small volume of trees harvested with clear-cutting methods led to satisfactory productivity, from 6 to $24 \mathrm{~m}^{3} \mathrm{PMH}_{0}{ }^{-1}$, in spite of harvesting residues of ca. $7 \%$ of the total biomass that were left on the harvesting sites.

In a final research from Finland, the impact of the remaining young spruce understorey on the cutting productivity in 


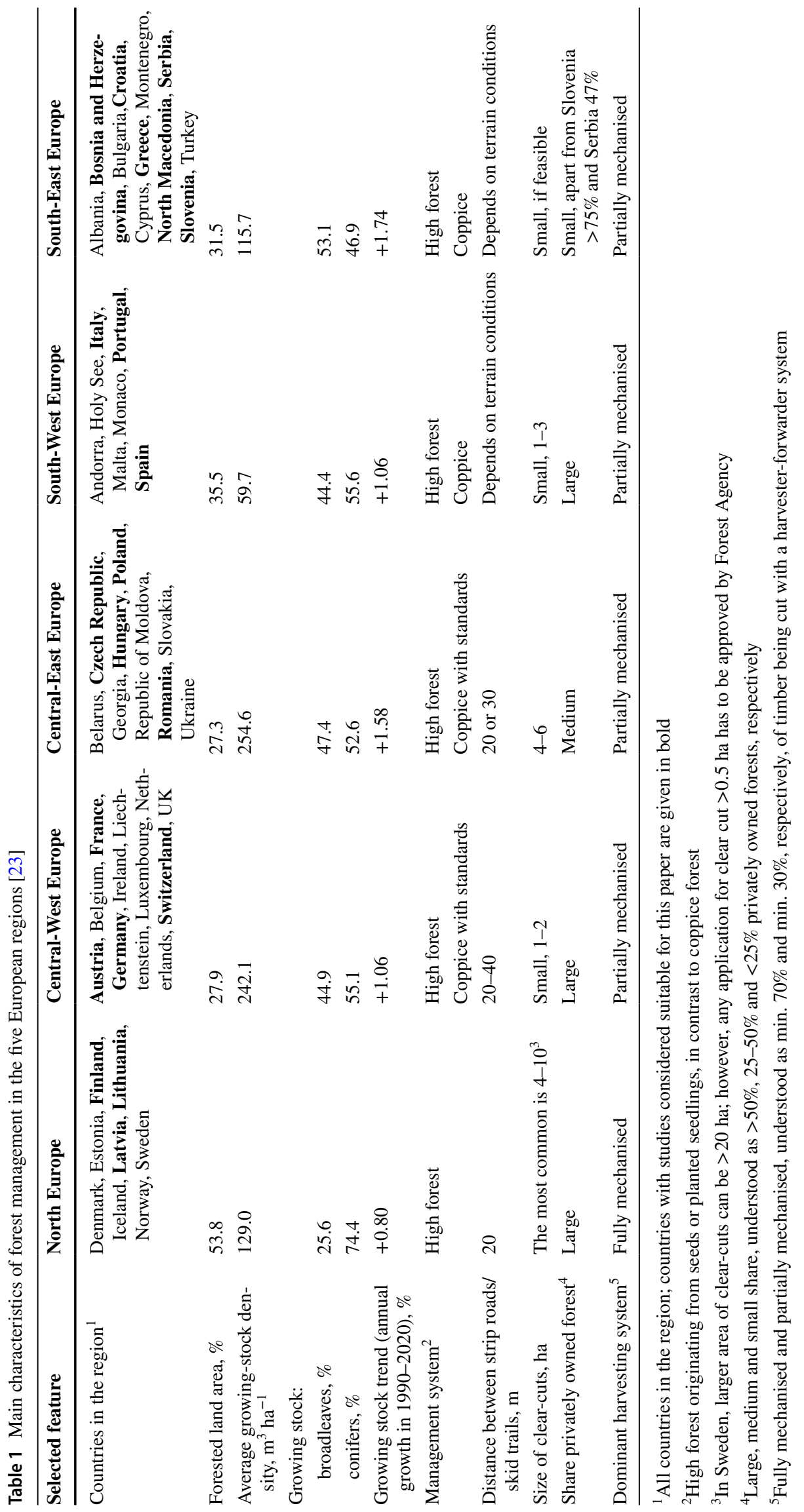


thinning stands dominated by downy birch was investigated [27]. Tests were carried out on 50- to 75-year-old birch trees with a mean diameter at breast height (DBH) from 14 to $24 \mathrm{~cm}$. A medium-sized John Deere 1070/745 with a boom reach of $10 \mathrm{~m}$ was used in the study. Different productivities were achieved from 13 to $29 \mathrm{~m}^{3} \mathrm{PMH}_{0}{ }^{-1}$. In particular, productivity was $15-29 \mathrm{~m}^{3} \mathrm{PMH}_{0}^{-1}$ in thinning stands where there were no spruce trees present, $14-24 \mathrm{~m}^{3} \mathrm{PMH}_{0}{ }^{-1}$ in stands where spruce trees were present but were not considered, and $13-21 \mathrm{~m}^{3} \mathrm{PMH}_{0}{ }^{-1}$ in stands where spruce undergrowth was retained.

In Latvia, grey alder is an important tree species in the management of non-state forests. Motor-manual felling is a common method in non-state forests, but fully mechanised forest operations are carried out in final felling. Liepinšs et al. [28] examined the effectiveness of motor-manual and mechanised harvesting, in which productivity reached 2.99 and $7.04 \mathrm{~m}^{3} \mathrm{PMH}_{0}{ }^{-1}$, respectively. In spite of the lower productivity, motor-manual harvesting was more cost-effective than mechanised forest operations. It was also concluded that improvements in work organisation that could lead to higher productivity and a potential increase in labour costs in the near future may increase the financial competitiveness of mechanised harvesting.

It was reported that the average cost for final felling in Latvia, including cutting, off-road transport and further transportation to the customer, reached $16.54 € \mathrm{~m}^{-3}$ in 2015 [29]. For these three specific operations, the calculated costs were similar at 5.70, 4.94 and $5.90 € \mathrm{~m}^{-3}$, respectively [17]. In thinning operations, the average cost was $21.60 € \mathrm{~m}^{-3}$ but was more differentiated: 9.39, 6.14 and $6.07 € \mathrm{~m}^{-3}$, respectively $[17,29]$. Differences in harvesting costs depended mostly on the type of felling (thinning or final felling) but also on forwarding conditions, such as soil bearing capacity and forwarding distance. However, there was no evidence that tree species composition had a significant impact on harvesting costs.

A study on product quality was carried out on birch and aspen in Lithuania and indicated that keeping a stable length of $\operatorname{logs}$ is a challenge for harvesters. Zinkevicius et al. [26] reported that, for birch and aspen logs, the length accuracy of cut $\log$ s by a motor-manual operator was better than the accuracy of bucking by the CTL $40 \mathrm{HW}$ harvester head designed specifically for broadleaved tree species.

\section{Central-West Europe}

In Central-West (CW) Europe, about $28 \%$ of the land area is forested (38.966 mln ha) [23]. The average growing-stock density is $242 \mathrm{~m}^{3} \mathrm{ha}^{-1}$, whereas Switzerland $\left(354 \mathrm{~m}^{3} \mathrm{ha}^{-1}\right)$, Germany $\left(321 \mathrm{~m}^{3} \mathrm{ha}^{-1}\right)$ and Austria $\left(299 \mathrm{~m}^{3} \mathrm{ha}^{-1}\right)$ represent the upper limit. Overall, the growing stock is increasing in this region. The most common management system is high forest, which can be even-aged management, continuous cover forestry or uneven-aged forestry. One exception is France, which has a large share of broadleaved tree species (64\%) and where around 30\% of the total forest area is traditionally managed as coppice with standards [30]. A large share of the forest area in CW Europe is managed using forest strip roads with 20- to 40-m distance between them, and with restrictions limiting penetration by any machine in the zone between the strip roads. Again, France is an exception, as it doesn't make use of a defined strip road network [31].

Since clear-cuts are usually tolerated for small areas only in CW Europe (e.g. $<1$ ha in Germany, $<2$ ha in Austria), the dominant harvesting system is selective cutting, which is conducted in a motor-manual system, partially mechanised system (i.e. motor-manual felling and mechanised processing) or fully mechanised system. The choice depends on the strip road density but also on the forest ownership. There is a large share of privately owned forests (almost $75 \%$ in France, approx. 50\% in Austria and Germany). Owners are responsible for small forest areas only and do not make large investments. The trend to use light and less specialised machines can be observed in coppice forests as well, which is consistent with the rural and small-scale character of coppice forestry [30]. The majority of fully mechanised felling operations are carried out by contractors e.g. approx. $90 \%$ in Germany [32]. In hardwood stands, the share of fully mechanised harvesting operations is only about $10-20 \%$. Schuldt [33] assessed the status of partially and fully mechanised harvesting methods for hardwood stands, thereby focusing on a medium DBH of $20-35 \mathrm{~cm}$. He recognised that a machine with at least a medium-sized engine power is needed and that it should be run by a skilled operator. Smaller harvesters were not considered suitable because they have a shorter boom reach and thus require a denser network of strip roads, as confirmed by Mederski et al. [34]. Selected studies included in this paper were from Austria, France, Germany and Switzerland.

Labelle et al. [35] conducted a pilot study consisting of 82 sample plots in a 4.5-ha beech-dominated mixed stand in Germany, aiming to assess the influence of silvicultural management (selective-cut vs clear-cut) and tree species (spruce vs beech) on the performance of the analysed harvester. The stand had an average age of 90 years and an estimated volume of $280 \mathrm{~m}^{3} \mathrm{ha}^{-1}$. A six-wheeled single-grip harvester was used for the felling operation (2005 TimberPro 620-E equipped with a LogMax $7000 \mathrm{C}$ harvester head). The resulting felling productivity for beech trees was $24.7 \mathrm{~m}^{3} \mathrm{PMH}_{0}{ }^{-1}$ $\left(23.4 \mathrm{~m}^{3} \mathrm{PMH}_{0}{ }^{-1}\right.$ in selective-cut and $27.5 \mathrm{~m}^{3} \mathrm{PMH}_{0}{ }^{-1}$ in clear-cut). This was, however, $31-45 \%$ lower than the productivity observed in spruce stands $\left(33.9 \mathrm{~m}^{3} \mathrm{PMH}_{0}{ }^{-1}\right.$ in selective-cut and $36.0 \mathrm{~m}^{3} \mathrm{PMH}_{0}{ }^{-1}$ in clear-cut). Processing was more time consuming in selective-cut compared with clear-cut operations, due to larger tree diameters (DBH 41 
cm vs $32 \mathrm{~cm}$ ). In another pilot study, [36•] observed four harvesters (two-wheeled and two-tracked machines) that worked in four different plots with a high percentage of large-diameter trees (oak, European beech). Two operations were conducted on a fully mechanised basis and processing was the most time-consuming step, taking $54-65 \%$ of the time per cycle. The harvesting productivity varied between 29 and $43 \mathrm{~m}^{3} \mathrm{PMH}_{0}^{-1}$ on average.

In France, the mechanised processing of logs from large crowns of broadleaved species is of particular interest. Ruch et al. [37] compared two harvesting systems, the first with a grapple saw that was attached to a forwarder and the second with the grapple saw that was attached to an excavator which processes the crowns for a forwarder. The one- and two-machine systems were analysed in terms of productivity, efficiency and technical and economic aspects. Nine key factors influencing productivity were identified. The authors concluded that (i) the grapple saw is an easy-to-use piece of equipment which is efficient and requires a comparably small investment for the contractor $(15,000 €)$, and (ii) the single-machine system performs best, with costs varying between 8 and $14 € \mathrm{t}^{-1}$, compared with 20 to $23 € \mathrm{t}^{-1}$ for a two-machine system. Several studies (e.g. [38]) have been conducted in France to observe the current productivity of applied hardwood harvesting systems. These studies indicated that there was a significant increase in the productivity of the machines involved in hardwood harvesting in recent years (around $+22.7 \%$ from the period of 2000-2007 to 2008-2015) but that the rate of mechanisation of hardwood cuts remains low (but increased from 10\% in 2013 to around $15 \%$ in 2018) [39]. The technical complexity of dealing with the most poorly shaped hardwoods, combined with the absence of an ideal harvester head, could explain this observation.

Mechanised harvesting of hardwoods is mainly carried out by not only harvesting machines in CW Europe, but also by modified excavators equipped with harvester heads [40]. As there is no specific harvesting machine dedicated to hardwoods, a lower annual volume was harvested in broadleaved stands, i.e. $14,000 \mathrm{~m}^{3}$ year $^{-1}$ machine ${ }^{-1}$, compared with $23,500 \mathrm{~m}^{3}$ year $^{-1}$ machine ${ }^{-1}$ observed in softwood stands in France [40].

Even though less important than high forests, traditional (and partially modern) coppice forests play a role in CW Europe. Machines larger than traditional forestry tractors are increasingly being used for coppice felling and processing [30]. Suchomel et al. [41] determined the technical feasibility and the time consumption of harvesting oak coppice with an average DBH of $17.5-18.2 \mathrm{~cm}$. They investigated an HSM 405H 6WD harvester with a CTL 40HW harvester head and found an overall productivity of $9.5 \mathrm{~m}^{3} \mathrm{PMH}_{0}{ }^{-1}$ for trees with a DBH $>10 \mathrm{~cm}$ and an average stem volume of $0.17 \mathrm{~m}^{3}$. The main advantage of the studied harvester was observed for larger diameters: the productivity increased to $14 \mathrm{~m}^{3} \mathrm{PMH}_{0}{ }^{-1}$ at a stem volume of $0.20 \mathrm{~m}^{3}$. The multistem structure did not result in technical problems or a significantly greater time consumption for the harvester, even though it was slightly more time-consuming to grab and fell multi-stemmed trees than single-stemmed trees. Compared with manual felling, the harvester left significantly $(5 \mathrm{~cm})$ taller tree stumps, although [42] showed that mechanised cutting does not seem to have any negative effects on coppice regeneration and growth.

Fully mechanised hardwood harvesting depends mainly on the harvester head or the fuelwood feller unit. Using softwood harvester heads in hardwood stands is technically difficult. Nordic products are light and handy, but felling heads have been constructed for tree species with less dense wood [43]. On the other hand, North American felling heads are more robust and powerful but must be mounted on heavy machines, which stands in conflict with soil protection issues and Central European silvicultural practices [44]. Chakroun et al. [44] performed a study in which two recently developed fuelwood feller units from French manufacturers were compared in typical hardwood biomass forests: (a) thinning in regular high forest and (b) clear-cutting in coppices. The feller units were tailored for the tree species available in Central and South Europe, allow multi-tree handling, and were designed to be mounted on medium-sized excavators. The main findings of the study were that the significant factors influencing productivity were tree size and stand type (with productivity generally higher in high forests), with values ranging from 5.7 to $17.1 \mathrm{~m}^{3} \mathrm{PMH}^{-1}$.

Kleinschmit [45] aimed to determine the economically optimal processing intensity of beech crowns in Germany. He conducted trials with highly mechanised systems using a John Deere harvester 1270E IT4 with a Waratah felling head H480C developed for timber of large dimensions. Kleinschmit examined the processing of beech trees and presented a decision model with the aim not only of explaining the economic relationships of crown processing, but also of assisting decision makers in determining the economically optimal processing intensity or the economically optimal top diameter and raising their awareness of the cost dependencies in the case of changed economic framework conditions. Branches with a $>7 \mathrm{~cm}$ over-bark diameter could be identified as cost drivers. These branches require additional time consumption of about $24 \mathrm{~s}$ just for cutting. Processing logs with branches took five times longer than processing logs with the same length but from tree parts without branches.

Cacot et al. [46] performed a study on a new type of delimbing tool for hardwood trees in France: oak, chestnut, birch and aspen. The focus was on the shape of the delimbing knives modified by the integration of ribs in the cutting area. In a first step, several types of knives were compared 
in the laboratory in terms of the energy required for cutting. Based on this evaluation, two harvester heads, each equipped with one fixed and two mobile ribbed knives (John Deere 752 HD, Kesla 25 RH harvester head), were compared with the original knives over 1 year. Using the ribbed knives led to an increase in productivity by $21 \%$ in the delimbing process, although the increase in overall productivity could not be proven statistically.

For several reasons (e.g. work safety, salvage logging, lack of own personnel), some state forest administrations and federal research institutes within CW Europe actively promote fully mechanised hardwood felling. The Austrian Research Centre for Forests (BFZ), for instance, published a video [47] in which they state that a major challenge is the undergrowth and argue that the basic requirement for a successful operation is good visibility of the strip roads, the future crop trees and the trees selected for removal.

The potential for future mechanised hardwood harvesting in CW Europe is significant. In recent years, France seemed to be very active in developing and testing solutions for mechanised harvesting of hardwood species. This can be explained mainly by its forest structure. Current trends show that companies are reacting to the demands of practitioners. This development is also driven in part by climate change [48] and its associated impacts (e.g. dying ash and beech trees). In Switzerland, a fully commercial technical solution was designed and constructed to safely and efficiently fell hardwoods, including large trees, that might be dry or affected by illness. In this solution, a safety platform is mounted on a felling excavator with a $15-\mathrm{m}$ boom using a quick-change system. The trees are held by the excavator grapple during the felling operation and the safety platform then encloses the stem and protects the feller from falling branches and crown parts. After the feller has left the area of danger, the tree is safely moved by the excavator in the desired felling direction [personal communication with Weber, 2021].

\section{Central-East Europe}

In Central-East (CE) Europe, $27.3 \%$ of the land area is covered with forest $(44.735 \mathrm{mln}$ ha), with broadleaved and coniferous stands summing to ca. $40 \%$ each and mixed stands to ca. 20\% [23]. CE Europe is the richest area in terms of growing stock, at $254.6 \mathrm{~m}^{3} \mathrm{ha}^{-1}$, with the highest values in Romania ( $339.8 \mathrm{~m}^{3} \mathrm{ha}^{-1}$ ), the Czech Republic $\left(295.4 \mathrm{~m}^{3} \mathrm{ha}^{-1}\right)$ and Poland $\left(287.9 \mathrm{~m}^{3} \mathrm{ha}^{-1}\right)$ [23]. The majority of areas are managed in the form of high forest as even-aged and uneven-aged stands. Coppice forests are rare and tend to be grown as coppice with standards. Stands are accessible by machines with networks of strip roads, with a distance between them of $20 \mathrm{~m}$ for harvesters and ca. 30 $\mathrm{m}$ for skidders. Exceptions exist in the mountains, where the distribution of the strip road network is irregular and depends mainly on the land configuration.

The dominant harvesting system in CE Europe is selective cutting, which is used in all premature stands. Clear-cuts are usually applied on a maximum area of 4 ha, with the exception of 6 ha in Poland. CTL technology used during thinning and final felling covers $38 \%$ of the total harvesting in the Czech Republic and 40\% in Poland [18••, 49, 50], compared with only $5 \%$ in Slovakia and $2 \%$ in Romania [17]. In CE Europe, CTL technology is used mainly for coniferous species, but harvesters can be used for broadleaved species as well, such as birch [51, 52••], oak [53], alder $[54,55]$ and aspen and poplar $[56,57 \bullet \bullet]$. However, broadleaved species can be seen as a factor limiting harvester use in CE Europe, including in mountainous areas [15]. Taking into account the distribution of harvesters and the share of broadleaved species in the analysed region, it can be concluded that ca. 10-15\% of hardwood timber in Poland is obtained by harvesters, while in other countries, such as the Czech Republic, Slovakia, Romania and Hungry, timber from broadleaved stands is rarely produced with fully mechanised technologies.

Studies on the productivity of harvesters when processing the timber of broadleaved species have shown that it may differ from values for harvesting coniferous trees in CE Europe. In earlier studies carried out by Mederski et al. [58] in Poland, harvester thinning operations in broadleaved mixed stands (mainly birch) resulted in a productivity of $13.40 \mathrm{~m}^{3} \mathrm{PMH}_{0}^{-1}$. This study was based on a harvester head specially designed and built for broadleaved species: CTL 40HW. A much higher productivity was achieved when harvesting 46- and 61-year-old birch with a Sampo Rosenlew 1066 and Keto 150LD head [51]. In the study, productivity reached 26.95 and $40.46 \mathrm{PMH}_{0}{ }^{-1}$ in younger and older stands, respectively, and was higher by $44 \%$ and $41 \%$, respectively, in comparison with productivities achieved when harvesting pine of the same age. These differences were mainly due to tree size (birch had a larger volume) and, of considerable importance, to the fact that birch logs with a diameter over bark of up to 12.3 and $16.2 \mathrm{~cm}$ were processed in younger and older stands, respectively. In comparison, processing of pine was more effective for log diameters of up to 9.4 and $10.6 \mathrm{~cm}$ over bark in younger and older stands, respectively [51].

In another study using a large pool of data in Poland [59], the mean productivity of $15.77 \mathrm{~m}^{3} \mathrm{PMH}_{0}^{-1}$ when harvesting broadleaved species was lower than the productivity achieved in pine stands, which varied from $18.57 \mathrm{~m}^{3}$ $\mathrm{PMH}_{0}{ }^{-1}$ in younger stands (41-60 years old) to $22.60 \mathrm{~m}^{3}$ $\mathrm{PMH}_{0}{ }^{-1}$ in older stands (81-100 years old) [19]. In other studies in Poland, in which a Ponsse harvester was used with head $\mathrm{H} 7$, the productivity of oak was $20.32 \mathrm{~m}^{3} \mathrm{PMH}_{0}{ }^{-1}$ for harvested trees with a mean DBH of $20.0 \mathrm{~cm}$ and $0.25 \mathrm{~m}^{3}$ 
of timber was harvested from one tree on average [53, 60]. The interesting aspect of this study was the use of tree trunks for logs. It was demonstrated that the mean top diameter over bark of the last log (from the highest tree part) was $13.3 \mathrm{~cm}$ when attempting to process logs up to the smallest diameter of $7.0 \mathrm{~cm}$ over bark. It was also confirmed that the top diameter of the last log depended on the DBH of the tree from which that log was obtained. It is a challenge to make harvesting small trees profitable. A study on harvester use in an 8-year-old poplar plantation in Poland showed that productivity reached $7.5 \mathrm{~m}^{3} \mathrm{SMH}^{-1}$ (scheduled machine hours, with delays) when the multi-tree harvesting mode was used and $6.5 \mathrm{~m}^{3} \mathrm{SMH}^{-1}$ in single-stem processing [57••].

The quality of delimbing was studied extensively by Mederski [51] in a comparison of pine and birch logs. The two tree species were analysed separately in two mixed stands in Poland with ages of 46 and 61 years. Testing of the quality of delimbing was carried out as measurements of stubs left after delimbing with a Keto 150LD head. The largest stubs were observed on the birch logs from older trees, with a mean stub length of $34 \mathrm{~mm}$, while on the birch logs from the younger stand, the mean stub length was only $26 \mathrm{~mm}$. On the pine logs, the stubs were significantly smaller: 13 and $12 \mathrm{~mm}$ on logs from older and younger trees, respectively. Within this study, the accuracy of log length was also considered, and it turned out that the cross-cutting accuracy was highest for the butt ends of the older pine stand (more than $60 \%$ of the logs had a very narrow length tolerance set in the harvester computer: $2.53-2.55 \mathrm{~m}$ ). The least accurately cut logs within this category were the top pine assortments obtained from the younger stand (ca. $45 \%$ of logs within the specified range). Better results were obtained when the CTL 40HW harvester head was used for birch and aspen. The log length accuracy of birch and aspen showed that more than $80 \%$ of the thicker birch and aspen logs (from the bottom part of the trunk) met the target length $(2.50 \pm 0.05 \mathrm{~m})$, while only $70 \%$ and $50 \%$ of the thinner birch and aspen logs, mainly from top parts, reached the target [56].

An interesting study was carried out by Karaszewski et al. $[54,55]$ in which log quality was defined as the extent of damage from feed rollers in the outer layer of round wood. This kind of damage can be especially dangerous for pine wood harvested in summer, as blue-stain can develop and reduce timber quality. In broadleaved species, it is unwanted damage, especially in plywood, where outer layers are of the highest value. Karaszewski et al. [55] reported that damage from feed rollers on birch plywood logs can reach depths of $3.9 \mathrm{~mm}$ and cause a $4 \%$ volume loss.

In 2013-2016, a project was completed for the State Forests $^{1}$ in Poland, with the aim of selecting the most suitable

\footnotetext{
${ }^{1}$ Potential of harvester use for broadleaved tree species (Możliwości zastosowania harwesterów do pozyskiwania drewna gatunków liściastych) - E0-2717-22/13; 2016; supported by the General Directorate of the State Forests, Poland, 2013-2016.
}

harvesters for felling and processing timber of the four most common and economically important broadleaved species in the country: oak, beech, birch and alder. All tests were carried out in 40- to 80-year-old stands. Harvesters of 11 different producers were tested with 11 different heads. Trials were carried out on 60 sample plots in North Poland and the considered parameters of harvester efficiency were the following: (1) productivity, (2) cost, (3) range of trunk utilisation for logs, (4) length accuracy, (5) quality of delimbing and (6) damage to logs. Considering all of these parameters, the best results were achieved when a Waratah head was used, although good results were also obtained with heads by Ponsse and Valmet. The average productivity was $15.77 \mathrm{~m}^{3} \mathrm{PMH}_{0}^{-1}$ in all analysed stands, with maximum productivity reaching $36.16 \mathrm{~m}^{3} \mathrm{PMH}_{0}^{-1}$ in oak stands with a mean DBH of $28 \mathrm{~cm}$. Generally, higher productivity was achieved in alder stands, where larger trees were harvested. It was also discovered that tree tops with larger diameters (in comparison to coniferous species) are typically left, as a result of difficulty delimbing in tree crowns. Overall, the completed project popularised harvester use for broadleaved species in Poland and convinced forest owners and forest entrepreneurs to consider wider harvester use in broadleaved or mixed stands.

The CTL 40HW harvester head, developed in 2005-2007 within the ForstINNO ${ }^{2}$ project, was a new harvester head dedicated to broadleaved species and tested in CE countries. The CTL 40HW was designed to cut trees with a maximum cutting diameter of $45 \mathrm{~cm}$. The head was equipped with only two movable knives to keep the head relatively short $(1270 \mathrm{~mm})$, in order to move with ease on the sweep along the tree trunk $[56,58]$. Another invention resulted from the cooperation of scientists from the Technische Universität Dresden (Germany), entrepreneurs from the business sector and researchers from the Poznań University of Life Sciences (Poland); a new idea for a harvester head was submitted in 2016 and the patent was granted in October 2021: Harvester head for hardwood $[61 \bullet \bullet]$.

\section{South-West Europe}

In South-West (SW) Europe, about 36\% of the land area is forested (31.466 $\mathrm{mln}$ ha) [23], with a dominance of broadleaved stands $(61 \%)$, followed by coniferous $(31 \%)$ and mixed stands (8\%). This region has the largest share of broadleaved stands and the lowest average growing-stock density $\left(60 \mathrm{~m}^{3} \mathrm{ha}^{-1}\right)$ in the European context, with the lowest values in Portugal $\left(52 \mathrm{~m}^{3} \mathrm{ha}^{-1}\right)$ and Spain $\left(60 \mathrm{~m}^{3} \mathrm{~h}^{-1}\right)$ varying considerably from the growing stock of $149 \mathrm{~m}^{3}$

\footnotetext{
${ }^{2}$ ForstInno: Development of an ecologically compatible, highly productive method of timber harvesting for Central European forestry - COOP-CT-2005-512681; supported by EC in $6^{\text {th }}$ Framework Programme, 2005-2007.
} 
ha $^{-1}$ in Italy. On the contrary, there is a trend of an annual increase in terms of growing stock in this region, at a rate of $+2.30 \%$ over the period 1990-2020, which is the highest in Europe and can be partly attributed to the expansion of forest area in this region. Nevertheless, it should be noted that the amount of felling has markedly increased in all European regions since 1990 but not in SW Europe.

All types of forests can be found in all three above mentioned countries of SW Europe, ranging from natural woodland to remarkably large forest plantations. Fast-growing plantations aimed at timber or wood-pulp production, such as those of poplar in the Po valley, have a rotation period of around 10 years, whereas other plantations focused on the production of particularly valuable timber (e.g. walnut, maple, ash and cherry) have considerably longer rotation periods [62]. Plantations of eucalyptus in Central-West Portugal have been identified as one of the most intensively managed forested areas in Europe [63]. Large plantations have also been established in Spain following the decision to increase the share of energy from woody biomass to the national energy mix [64].

Coppice forests are widely distributed in SW Europe. Different management strategies are implemented in the region, including the conversion of coppice forests to high forests, which, given that it is a long and expensive activity, is unattractive to private owners. Clear-cutting is allowed in some cases, but law requires that some stands are left to favour seed production and sprout regeneration from old stumps [62]. Given the ecosystem services provided by coppice forests, especially in terms of soil protection from erosion, coppices are gaining in importance, yet their utilisation remains problematic. In most cases, a medium level of mechanisation is implemented, consisting of motor-manual felling and mechanised extraction. The extent of mechanisation is highly variable, ranging from limited on steep terrain to fully mechanised in productive poplar sites like in the Po valley [62]. In most cases, clear-cutting is applied to limited areas in natural forests, as in the case of light-demanding species (larch and pines), in order to meet the ecological requirements of these species and facilitate the natural regeneration of the stands. On the contrary, selection and shelterwood harvesting systems are strongly encouraged. Coppice harvesting technology has evolved in the last decades [30]. In these stands, mechanical felling and processing can be applied, and there is a trend of increasingly large machines in coppice operations, as is occurring in high forests and plantation operations [65]. However, lighter and less specialised machinery than that used in high forests has been used so far in coppice forests. Thus, relatively cheap and versatile general-purpose machines (excavators, light forwarders and farm tractors) continue to make up the largest part of coppice machine fleets, compared with heavier and more expensive forest machinery [30].
In SW Europe, the deployment of harvesters is often not possible due to difficult terrain [66], legislation or limited financial capacity [67]. New winch-assisted technology may soon provide a technical solution to the terrain limitation; nevertheless, deep structural changes in the legislative and economic environment would be necessary to promote harvester adoption and use [68]. On the contrary, excavatorbased units, whose popularity is low in North and Central Europe, are quite popular in SW Europe, as a result of their lower investment cost and their higher operational flexibility [69-]. Italy is an exemplary case, with three out of every four harvester and processor heads mounted on adapted, often pre-owned, excavators, indicating a low willingness to invest in newer machines in an effort to minimise the associated financial risk [70]. In this section, representative studies on mechanised harvesting of broadleaved tree species were carried out in Italy, Portugal and Spain.

Magagnotti et al. [71] compared two strategies for chip and firewood production at two technological levels of mechanisation in thinning operations in Italy. Thinning was carried out with two methods: as a whole tree system (WTS) in partially mechanised operations and as the short-woodsystem (SWS) in CTL technology. In the WTS, trees were initially felled and gathered in bunches of five to eight pieces by a 13-tonne excavator equipped with a chainsaw felling head and then extracted with a $75-\mathrm{kW}$ farm tractor equipped with a log grapple. In the mechanised treatment, felling, processing and stacking were performed in one sequence by a harvester, based on a 13-tonne wheeled loader. All manual operations were carried out by chainsaw. The best results were achieved with mechanised harvesting, which caused less stand and soil damage compared with manual harvesting. In mechanised WTS and SWS, higher productivities were achieved than with the motor-manual methods (15.48 $\mathrm{t} \mathrm{PMH}_{0}{ }^{-1}$ vs $9.27 \mathrm{tPMH}_{0}{ }^{-1}$ in WTH and $5.35 \mathrm{t} \mathrm{PMH}_{0}{ }^{-1}$ vs $0.87 \mathrm{tPHH}_{0}{ }^{-1}$ in SWS). In terms of cost, WTS was practically the same $\left(5.8 € \mathrm{t}^{-1}\right.$ for manual vs $6.1 € \mathrm{t}^{-1}$ for mechanised); however, mechanised SWS $\left(22.4 € \mathrm{t}^{-1}\right)$ contributed to a significant cost reduction over manual SWS $\left(34.9 € \mathrm{t}^{-1}\right)$.

The mechanised thinning of walnut plantations was also examined in Italy [72]. The authors tested two low-investment fully mechanised operations for producing chips (T1) or traditional firewood (T2) from the thinning of walnut plantations. In the first thinning operations (T1), a 4-tonne skid-steer loader equipped with a disc saw felling head was used to fell alder trees and accumulate them in bunches of five to eight pieces, which were later extracted by a farm tractor with a log grapple. In the second treatment (T2), a 95-kW farm tractor equipped with a hydraulic loader and a small-scale stroke harvester was used to fell and process the trees. The same machine was later converted into a forwarding unit by replacing the harvester with a log grapple and attaching a forestry trailer to the tractor. The equipment used 
in $\mathrm{T} 1$ was less costly than in $\mathrm{T} 2\left(54.0 € \mathrm{~h}^{-1}\right.$ vs $\left.88.5 € \mathrm{~h}^{-1}\right)$ and offered a higher felling productivity of $11.74 \mathrm{t} \mathrm{PMH}_{0}{ }^{-1}$ compared with $2.40 \mathrm{t} \mathrm{PMH}_{0}{ }^{-1}$. Furthermore, mechanised firewood harvesting, as examined in $\mathrm{T} 2$, was financially less effective than traditional motor-manual operations. Given the price levels during the data collection period, smallscale mechanised chipping was more profitable than motormanual firewood production along the full tree size range. Chipping achieved a financial profit, even with smaller trees than used in firewood production, suggesting that early thinning operations can be economically viable when they are carried out in a timely manner before the nurse trees overtop the crop trees.

A harwarder is a combined machine used for timber cutting, processing and forwarding. A small and a large harwarder ( $\mathrm{SH}$ and $\mathrm{LH}$ ) were tested during thinning in hardwood plantations established on agricultural land in Italy [73]. Two treatments were carried out: whole tree sections (WT) or integrated harvesting (IH) - firewood logs joined with tree tops. The thinning resulted in a yield of $45 \mathrm{t}$ of fresh biomass per hectare. The average gross productivities of the $\mathrm{SH}$ and the $\mathrm{LH}$ during the WT harvesting treatment were 3.46 and $2.77{\mathrm{t} \mathrm{PMH}_{0}}^{-1}$, respectively. The SH was more efficient at felling and loading, while the LH was more efficient in the terrain transport work. The productivity of both machines was about $15 \%$ lower in the IH treatment. The harvesting cost ranged between 18 and $34 € \mathrm{t}^{-1}$, with the LH having a higher operational cost than the SH. With both machine types, the harvesting cost decreased as the stem size of the harvested trees increased.

Suchomel et al. [74] studied the efficiency of four different harvesters used in Italy for delimbing and bucking of chestnut trees from coppice stands. The machines were as follows: an Arbro 400S on a JCB 8052 excavator, a Foresteri RH 25 on a CAT 312 L excavator (in two sites), a Lako 55 Premio on a JCB JS 180 NL excavator and a Timberjack 1270B dedicated harvester with a John Deere $762 \mathrm{C}$ head. Trees were processed at the landing in order to minimise the impact of machine movement on productivity. The processors reached high productivity values ranging from 5.4 to $19.8 \mathrm{~m}^{3} \mathrm{PMH}_{0}^{-1}$. Furthermore, the influence of tree form was estimated in the Arbro 400S study. The size of the branches and the shape of the stem had a significant effect on machine productivity, which could reach $2.3 \mathrm{~m}^{3} \mathrm{PMH}_{0}{ }^{-1}$ for stems with a volume of $0.2 \mathrm{~m}^{3}$. The study showed that mechanical processors can be successfully deployed for handling whole chestnut trees from coppice stands, and that working at the landing and in coppice clear-cuts can improve the operational efficiency considerably.

Three harvesting systems were examined in a total of 11 sites in Q. pyrenaica Willd. coppice stands in Spain [64]. The harvesting systems included the following: 1) a mechanised whole tree system (WTS), which included chipping at the landing; 2) a fully mechanised CTL harvesting system for firewood; and 3) a semi-mechanised CTL system with manual felling and bunching. The biomass removal rate from heavy thinning ranged from 34.7 to 44.1 oven dry tonnes (odt) ha ${ }^{-1}$ for WTS, much higher than the range of 11.6-30.0 odt ha ${ }^{-1}$ obtained in CTL trials, a result that may be partially attributed to the larger average DBH in WTS. The WTS reached maximum productivity rates of $3.9 \mathrm{odt}$ $\mathrm{PMH}_{0}{ }^{-1}$ for the felling and bunching operation and 6.9 odt $\mathrm{PMH}_{0}{ }^{-1}$ for the forwarding operation. The mechanised CTL harvesting method achieved a lower productivity range of $0.5-1.3$ odt $\mathrm{PMH}_{0}^{-1}$ for the harvesting operation. Motormanual felling and cross-cutting in the CTL system resulted in a productivity range of $0.7-1.9$ odt $\mathrm{PMH}_{0}{ }^{-1}$. Manual bunching results ranged from 0.8 to 1.0 odt $\mathrm{PMH}_{0}{ }^{-1}$. The semi-mechanised CTL performed best in terms of firewood unit cost, at $62.0 €$ odt $^{-1}$ for trees with a DBH of $10 \mathrm{~cm}$ compared with $85.2 € \mathrm{odt}^{-1}$ for the fully mechanised CTL system. The chip production cost at the landing with the WTS (average DBH $=10 \mathrm{~cm}$ ) was $65.3 €$ odt $^{-1}$.

Poplar tree plantations are often established in sites with moist soil. Forest machine operation performance has been recognised as being dependent on soil moisture. Tavankar et al. [75] studied the effects of soil moisture content on productivity, cost and emissions of greenhouse gases (GHG) resulting from different harvesting systems (chainsaw-skidder and harvester-forwarder) in two poplar plantations in Italy and one in Iran. Both harvesting systems performed better in dry than in moist sites, with a higher productivity by $20-30 \%$. In Italy, poplar plantations are an important source of high-quality veneer logs. Although the conditions favour mechanised operations, the plantation owners indicate that mechanised log-making may result in value losses, due to poor length accuracy, log surface damage and improper grading. Spinelli et al. [12] studied the performance of manual and mechanised log-making in 10 commercial operations, in terms of occurrence and severity of possible value losses due to product degradation. Mechanised processing performed better with regard to length measurement errors, while the frequency and severity of log surface damage were the same for both treatments.

In a study by Magagnotti et al. [69•], the annual use, annual harvesting, productivity and fuel consumption of three purpose-built harvesters were compared with those of three excavator-based harvesters and processors after monitoring for 1 year. All machines were owned and operated by private contractors and were representative of the Italian machine fleet. Despite the challenging mountain terrain, annual use ranged from 675 to $1525 \mathrm{~h}$ per year, and annual harvesting volume from 3,200 to $27,400 \mathrm{~m}^{3}$ per year. Productivity was lower for excavator-based units (5.9 to 17.4 $\mathrm{m}^{3} \mathrm{PMH}_{0}{ }^{-1}$ ) than for purpose-built harvesters (12.7 to 21.8 
$\left.\mathrm{m}^{3} \mathrm{PMH}_{0}{ }^{-1}\right)$. Purpose-built machines offered higher annual use (69-83\% vs 48-69\%), and reduced fuel consumption (8.4-15.3 $1 \mathrm{PMH}_{0}{ }^{-1}$ vs 13.1-17.9 $1 \mathrm{PMH}_{0}{ }^{-1}$ ) compared with excavator-based machines.

Ferrari et al. [76] tried to determine the attitudes of North Italian logging contractors towards mechanised CTL technology, and to evaluate the potential of machine simulators when introducing mechanised harvesting for prospective users. In this context, a total of 74 valid interviews were carried out on study participants who had previously tested a forwarder simulator. The respondents were aware of the mechanised CTL technology potential, both in terms of productivity and safety. Respondents employed in firewood production were keener on the use of CTL technology. The main obstacles to the expansion of mechanised CTL technology in Italy at the time of the study were financial rather than technical. Thus, simplified low-cost machines specially designed for firewood production would be very attractive to Italian firewood contractors. As modern machinery makes use of computer technology, younger contractors are expected to be more interested in them. The promotion of mechanised harvesting can be enhanced by the use of simulators; however, new approaches that would maximise their benefit and compensate for their large cost must be deployed.

\section{South-East Europe}

In South-East (SE) Europe, 32\% of the land area is forested (40.887 $\mathrm{mln} \mathrm{ha}$ ). The average growing stock in this area is $116 \mathrm{~m}^{3} \mathrm{ha}^{-1}$, and in the last 30 years, the growing stock has increased by $1.74 \%$ (Table 1, [23]). In SE Europe, $78 \%$ of the forested area is under natural regeneration and expansion, while some countries such as Croatia and Slovenia reported a share of $>80 \%$. High forest is a common management system, and in most forest stands, beech accounts for one-third or slightly more of the entire growing stock. Bončina and Čavlović [77] state that presence of beech indicates closeto-nature management in Croatia, especially when compared with countries where beech dominates other potential forest vegetation. Most SE European countries, i.e. Slovenia, Bosnia and Herzegovina, Serbia, Montenegro, Macedonia, Albania and partially Croatia, manage beech forests by group selection and/or selection systems, which has preserved their natural form to a large extent [78]. While in Central and North Europe coppice forests comprise just a small share of the total forest area, this forest type covers a large part of the forest area in some countries of SE Europe, such as North Macedonia 59\%, Serbia 65\% and Greece 65\% $[79,80]$.

Climatic extremes have caused major problems with sustainable forest management that affect the quality of forest products (i.e. roundwood) in SE Europe, which has resulted in differences between the planned and produced assortment structure of processed timber and between planned and completed production revenues [81]. These differences mean that silvicultural operations are often carried out at the cost-

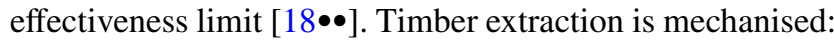
in all countries the number of skidders is higher than the number of forwarders, while felling and processing of timber are mainly motor-manual [82, 83, 84].

In SE Europe, secondary traffic infrastructure is divided into skid roads, i.e. constructed trails, on sloped terrain and skid roads in lowland forests. The distance between skid roads usually corresponds to the skidder's winch rope length and usually varies due to difficult terrain conditions, mainly slope configuration and river networks. It is generally agreed that $200 \mathrm{~m} \mathrm{ha}^{-1}$ is a dense road network on steep terrain in forests (managed in selection cutting) of European fir (Abies alba Mill.), Norway spruce and European beech [85, 86]. In lowland (even-aged) forests (in parts of Croatia and Serbia) where forwarders are in use, the distance between strip roads is usually $20-25 \mathrm{~m}$. Machines are required to stay solely on the strip road network, minimising soil and stand disturbance.

Motor-manual cutting dominates in SE Europe, mainly due to the diverse terrain and stand conditions and often due to the ownership structure affecting the introduction and use of CTL technology [87]. The large share of natural forests rich in broadleaved species with a large DBH, selection cutting and costs of motor-manual harvesting also limit wider use of CTL technology [88]. At the beginning of the twenty-first century, some SE European countries had an integral and controlled introduction of fully mechanised felling in cooperation with all the essential forestry stakeholders $[89,90]$. There were also previous applications of CTL technology in the 1990s, primarily associated with salvage felling in storm-damaged forests [91] or in clear-cuts of pine (Pinus sp.) and Douglas fir (Pseudotsuga menziesii (Mirb.) Franco) [92]. At that point, some authors have reported that harvesters could be successfully applied in thinning and clear-cutting operations in coniferous cultures and plantations of fast-growing deciduous species, as well as in pure alder (Alnus sp.) and ash (Fraxinus sp.) stands, just as effectively as in spruce (Picea sp.) stands. In other even-aged deciduous forests (e.g. oak and beech), the boundary factors of application are the dimensions of trees (DBH and stump dimensions), branching, type and intensity of felling and terrain conditions [89]. The authors highlighted that the use of harvesters is questionable in selection cutting, due to the management type and felling dimensions of the trees. Krpan and Poršinsky [89] concluded that the goals of fully mechanised felling are the following: raising productivity, lowering production costs, improving ergonomic aspects and avoiding a labour crisis in forest operations. Today, 20-30 years later, fully mechanised felling has become a regular feature in limited areas of SE Europe. 
Forest operations carried out with modern technologies are increasing in SE Europe, the experience gained by forestry companies and the forestry profession is growing, machines and technology solutions on the market are very diverse [91]. However, the number of published papers and completed studies regarding mechanised harvesting in broadleaved stands in SE Europe is still relatively small, and the experiences presented below come from Croatia, Serbia and Slovenia.

Shortly after the first introduction of harvesters in 2001 in coniferous stands in Croatia, it was reported that CTL technology could be effectively used in soft broadleaved stands i.e. willow (Salix sp.) and alder (Alnus sp.) [93]. The study, which used a Timberjack 1270B harvester, was carried out in a 23-year-old willow stand with a mean felling tree $\mathrm{DBH}$ of $25 \mathrm{~cm}$ and a volume of $0.5 \mathrm{~m}^{3}$. Machine productivity was $17.5 \mathrm{~m}^{3} \mathrm{PMH}_{0}^{-1}$, and clear-cutting, higher felling density and larger tree dimensions had a positive impact on machine productivity. In contrast, large crowns, preparation of the site for harvester operation (removal of a thick layer of shrubs) and an inexperienced (in broadleaved stands) harvester operator were detrimental, and minimisation of these factors would enhance harvester productivity to 27.5 $\mathrm{m}^{3} \mathrm{PMH}_{0}{ }^{-1}$. In the same year, [94] researched mechanised felling in 80-year-old thinned stands of sessile oak (Quercus petraea (Matt.) Liebl.), European beech and European hornbeam with the same harvester in Croatia. The researched stands had more or less similar stand features: growing stock $310 \mathrm{~m}^{3} \mathrm{ha}^{-1}$ and harvesting intensity $30 \mathrm{~m}^{3} \mathrm{ha}^{-1}$. Trees too thick for the harvester head were cut by a chainsaw operator, as were trees with large crowns. In the felling time structure, the harvester share was $81 \%$ and $19 \%$ of the remaining time was used for chainsaw operation. The authors concluded that the average productivity of felling and processing achieved by the joint operation of a harvester and chainsaw was 14.5 $\mathrm{m}^{3} \mathrm{PMH}_{0}{ }^{-1}$.

According to personal communication with Poršinsky (2021), the number of harvesters working in Croatia today is $>40$. If used in hardwood stands, they are usually involved in late thinning and preparatory felling operations (mostly with European hornbeam), often in combined mechanised and motor-manual cutting, due to the larger butt swelling of trees with a larger DBH, large crowns and thick branches. Vusić et al. [95] also researched mechanised timber harvesting in Croatia by a Timberjack 1470D harvester in 80-yearold European hornbeam and European beech harvesting sites, and concluded that European beech trees with a DBH $>52 \mathrm{~cm}$ (considering butt swelling) had to be felled and processed motor-manually.

An increase in the use of fully mechanised felling in both coniferous and deciduous stands was observed in the past decade in Slovenia [91]. An expansion of harvester use in deciduous stands in 2009 was due to harvesting in younger deciduous forests. As a result, in Slovenia, [87] reasearch was carried out leading to the evaluation of standard timetables for the most frequent commercial use of harvesters in thinning operations of coniferous and broadleaved trees. The authors reported that, in the case of broadleaved forked trees, there were frequent difficulties with tree processingthe feeding rollers and cutting knives of the harvester head did not develop sufficient force for the successful cutting of branches. Harvesters were only three times more efficient than motor-manual cutting. In another study in Slovenia in which the share of harvester use against motor-manual harvesting was considered, it was discovered that in salvage logging harvester use was more frequent than in standard, planned harvesting, where more or less half of the timber volume was cut with harvesters [96].

In Serbia, according to personal communication with Stojnić (2021), harvesters are used mainly for pine and poplar stands. Earlier studies from Serbia, [11] demonstrated the effect of forks on the productivity of a John Deere 1470D ECO III harvester in poplar plantations. The average maximum productivity ranged from 30.3 to $34.7 \mathrm{~m}^{3} \mathrm{PMH}_{0}{ }^{-1}$, depending on the working method. Harvester productivity was significantly affected by stem dimensions, within an average DBH of $40.4 \mathrm{~cm}$ and an average net volume of assortments per stem of $1.55 \mathrm{~m}^{3}$ stem $^{-1}$.

The first applications of fully mechanised systems in SE Europe date back to the 1990s to demonstrations from foreign contractors and were associated primarily with salvage cutting in storm-damaged forests [91] or conifer monocultures [89]. Since 2000, fully mechanised cutting has been used increasingly by contractors (mainly in Slovenia and Croatia), mostly by private forest enterprises. Krč [91] reported that in the Slovenian Forestry Service, companies and research institutions held many workshops to promote mechanised cutting. The author concluded that Slovenian entrepreneurs prefer investing in more universal machines, due to the greater chance of effective amortisation. Beguš and Krč [90] stated that the introduction of mechanised cutting in Slovenia was planned and its course was directed in an effective way by workshops held from 2002 to 2018 [96]. Slovenia was involved in the Quality Forest project (2017-2019), which addressed the challenge of elaborating new professional qualifications, focusing mainly on the European Chainsaw Certificate, but also on carrying out tree felling and processing with harvesters. According to Marčeta et al. [97], the use of a chainsaw and skidder is the most common harvesting system in Bosnia and Herzegovina. The authors promoted the planning of harvesting operations and investments with new CTL technologies and improved working methods using GIS and the Analytic Hierarchy Process (AHP) method. They proposed that using the AHP method, integrated with GIS software, would lead to improvement in the planning of forest operations, introduction of modern 
technologies to replace traditional forestry practice and ultimately selection of the optimal harvesting system.

Previous research on conifers in SW Europe already demonstrated how tree characteristics, such as forks, can negatively affect productivity, by up to $70 \%$ for trees of $10 \mathrm{~cm}$ DBH and by up to $50 \%$ for trees of $40 \mathrm{~cm} \mathrm{DBH}[87,88]$. Slovenian experiences shown that large, developed crowns have a negative influence on productivity, because the harvester's head is not able to develop a sufficiently high velocity for effective delimbing [89]. Further Slovenian research [98] indicated that time consumption per unit product should be determined to compare the economic efficiency of different technologies, and that the direct relationship between product output and time input is productivity. When comparing the productivity of fully mechanised harvesting systems in coniferous and broadleaved stands, other influencing factors should be taken into account, such as stem form (multi-stem, single-stem), forking, crown size, share of thick branches, butt swelling and stem sweep, all of which negatively affect productivity. In a recent study, it was observed that a mixed stand (60/40 coniferous to broadleaved) significantly affected the reduction of harvesting productivity, highlighting the importance of operator experience [99••].

\section{Conclusions}

Findings from the latest research on harvester applications in broadleaf-dominated stands indicate that there are different challenging factors in different European regions (Table 2). In North Europe, difficulties with harvester use for broadleaved species were observed in the multi-tree harvesting of trees with sweep; other difficulties were in accuracy of log length, while in Central (West and East) and South-East Europe, harvester use for broadleaved species has more potential limitations. The development of harvester heads dedicated to broadleaved species is mainly focused on Central Europe, where the share of broadleaved species and their particular morphological features (thick branches and sweep) are a major challenge for CTL technology. There have been research projects completed on this topic: in the last 15 years, there were a few larger initiatives leading to the design and development of harvester heads for broadleaved species, with participation from institutions and universities in France, Germany and Poland. There are currently no initiatives, but the formation of new ones is highly recommended because we currently manage and develop forests in a way that is different from how it was done in the last century.

North Europe is the region with the highest forest cover, but with the smallest share of broadleaves. The growing stock is average in comparison with other regions. A large share of coniferous species is advantageous for wide use of CTL technology, and this method is more popular in North
Europe than in the other regions. In the analysed latest published research, investigations into whether applications of multi-tree harvesting lead to higher productivity are common. At the same time, there are published findings on the difficulties of harvesting broadleaved species with sweep. Also, it is reported that keeping stable log length is challenging. It can be concluded that broadleaved trees in North Europe are characterised by rather thin branching and limited stem sweep in comparison with trees in Central Europe. Another argument for the influence of these morphological tree characteristics is that even though CTL technology has been developed for large-scale use in North Europe, there is no evidence of scientific findings leading to improved efficiency of broadleaved species harvesting with CTL methods. CTL technology application seems to remain a major challenge for Central European countries.

Central-West Europe is characterised by the second largest average growing stock of all European regions, with a large (44.9\%) share of broadleaves. In this region, there is an increasing interest and demand in all countries for mechanised hardwood logging, which is leading to the development of new technologies. However, most of them are produced individually by small manufacturers. The main factor driving increases in the share of broadleaved stands is climate change and its associated impacts i.e. shifts in species, increasing safety risks and economic effects. From a technical point of view, it is necessary to further adapt the harvester head to handle large crowns of hardwood species, especially those with forks and thick branches. Ribbed knives for harvester heads were tested, which lead to higher productivity. At the same time, machines should not become too large, since there is a trend towards using small and flexible machines, mainly for soil protection reasons. Given the current developments and the increasing pressure to provide hardwood timber in an economically efficient, safe and environmental-friendly manner, it can be expected that the development will continue to progress.

Central-East Europe is characterised by the largest growing stock of all European regions, with a very large (47.4\%) share of broadleaves. Wider harvester use occurs mainly in two countries, Poland and the Czech Republic, where up to ca. $40 \%$ of timber is harvested by CTL technology. There are recognised causes of limitations to wider harvester use, i.e. mountainous areas and broadleaved species, due to their morphological features (mainly sweep and thick branches), that lead to lower quality of delimbing, lower length accuracy, or large tree tops left unprocessed. For this reason, it is recognised that harvester heads require adjustments in design and construction to make timber processing more effective. It is also recognised that e.g. birch in CE Europe has different features to birch in Scandinavia or other parts of North Europe. Birch 


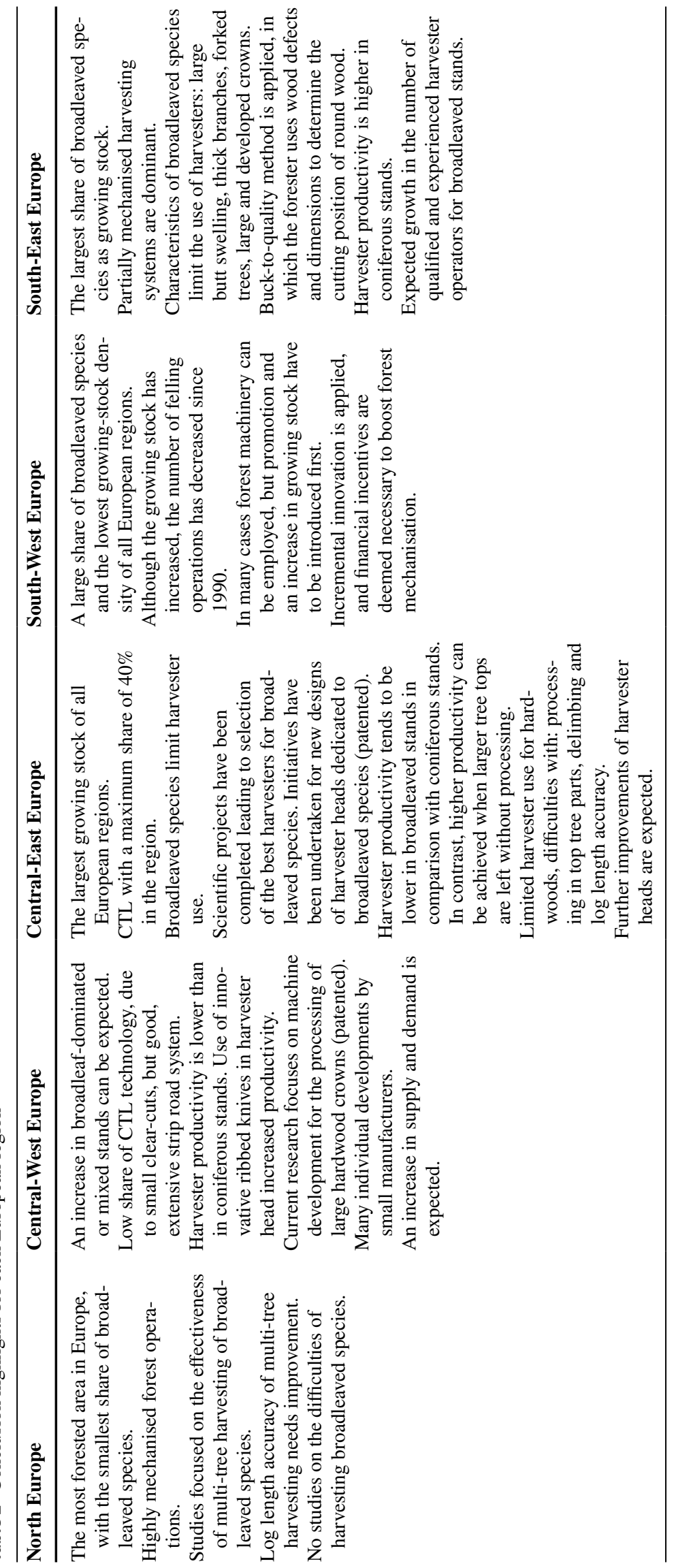


in CE Europe frequently has sweep and thicker branches, which make it more difficult to process. Therefore, scientific projects were carried out in last two decades in which selection of the best harvester heads for broadleaved species was an objective. Other projects were carried out (mainly in co-operation with scientists from Central-West Europe) and focused on the construction of heads with features making the processing of hardwood easier (e.g. the CTL $40 \mathrm{HW}$ head and new patent granted in October 2021: Harvester head for hardwood). In general, experiences with harvester use for broadleaved species indicate that productivity is lower than in harvester use with conifers. Higher productivity can be achieved only when large tree tops are left without processing. When using harvesters for plywood, damage of the outer layer was observed, which can lead to economic loses and a lower quality of logs. Harvester use for broadleaved species has become unavoidable, mainly due to significant changes in forest management leading to mixed or broadleaf-dominated stands and plantations. Therefore, it is expected that in the future, due to increases in broadleaved species shares in stands, improvements of harvester heads will be necessary to improve the effectiveness of CTL technology.

The region of South-West Europe represents an interesting case; despite having quite a large $(44.4 \%)$ share of broadleaves in the European context, the region also has the lowest growing-stock density. This fact inevitably affects the profits of forest entrepreneurs who are reluctant to invest in capital-demanding forest machines. Instead, local innovations are applied in the form of excavators equipped with harvester heads. However, their future deployment will depend on their fuel efficiency, where they are outperformed by more expensive, purpose-built harvesters. In SW Europe, past research on mechanised harvesting of broadleaved species has largely focused on coppice forests, agroforestry systems and firewood production. More research on mechanised harvesting is needed, as well as policy tools to promote and ease investments in CTL technology. In the face of climate change and the declining forest workforce, mechanised harvesting of broadleaved stands seems to be the missing link between more intensive and efficient forest utilisation.

South-East Europe is characterised by the largest share of broadleaved species in growing stock, and it has the greatest $(+1.74 \%)$ increase of annual growing stock. Even though the share of fully mechanised forest operations in this region is increasing, partially mechanised harvesting systems still prevail. The largest impact on harvester productivity in broadleaved stands comes from forked trees (thick branches), large and developed crowns and considerable butt swelling of the standing trees, especially for European beech, oak and European hornbeam, but in some cases even in poplar plantations. Another issue limiting the use of harvesters in broadleaved stands is the economically important buckto-quality method, in which foresters define timber assortments and select the most valuable ones. Similar to in other regions, there is an increasing demand for hardwood; therefore, it can be concluded that in the future, the development will move to fully mechanised harvesting operations.

Acknowledgements The authors thank Mr. Julian Muhmenthaler from WSL for supporting the French literature review. The authors are grateful to Professor Tomislav Poršinsky, PhD from the Faculty of Forestry and Wood Technology, University of Zagreb, and Mrs. Silvija Zec, president of the Croatian Chamber of Forestry and Wood Technology Engineers, for sharing information on the current number of harvesters in Croatia.

Funding The publication was co-financed within the framework of the Polish Ministry of Science and Higher Education's programme: "Regional Initiative Excellence" in the years 2019-2022, Project No. 005/RID/2018/19.

Data availability The authors confirm that the data supporting the findings of this study are available on request.

\section{Declarations}

Conflict of Interest The authors declare no competing interests.

Human and Animal Rights and Informed Consent This article does not contain any studies with human or animal subjects performed by any of the authors.

Open Access This article is licensed under a Creative Commons Attribution 4.0 International License, which permits use, sharing, adaptation, distribution and reproduction in any medium or format, as long as you give appropriate credit to the original author(s) and the source, provide a link to the Creative Commons licence, and indicate if changes were made. The images or other third party material in this article are included in the article's Creative Commons licence, unless indicated otherwise in a credit line to the material. If material is not included in the article's Creative Commons licence and your intended use is not permitted by statutory regulation or exceeds the permitted use, you will need to obtain permission directly from the copyright holder. To view a copy of this licence, visit http://creativecommons.org/licenses/by/4.0/.

\section{References}

Papers of particular interest, published recently, have been highlighted as:

- Of importance

$\bullet$ Of major importance

1. Martin P, Lapeyre D, Douchet O, Restoy G, Guegand G. Récolte mécanisée des taillis en bois ronds (Mechanised harvesting of roundwood from coppice forests). AFOCEL Fiche InformationForêt. 1996;4(540): 1-6.

2. Sionneau J, Cuchet E. Mechanisation of thinnings in hardwood, the French experience. In: Thinnings: A valuable forest management tool, IUFRO Unit 3.09.00 and FERIC, Natural Resources Canada and Canadian Forest Service, Québec, Canada. 2001; pp. 8. 
3. Kuitto PJ, Keskinen S, Lindroos J, Oijala T, Rajamäki J, Räsänen T, Terävä J. Puutavaran koneellinen hakkuu ja metsäkuljetus. Summary: Mechanised cutting and forest haulage. Metsäteho Report 410. 1994; pp. 38.

4. Nurminen T, Korpunen H, Uusitalo J. Time consumption analysis of the mechanised cut-to-length harvesting system. Silva Fenn. 2006;40(2):335-63.

5. Spinelli R, Owende PMO, Ward SM. Productivity and cost of CTL harvesting of Eucaliptus globulus stands using excavatorbased harvesters. Forest Prod J. 2002;52(1):67-77.

6. Bigot M. Using machines to harvest hardwoods in France. In: $24^{\text {th }}$ Council on Forest Engineering (COFE) "Appalachian Hardwoods: Managing Change", Snowshoe, WV, USA, 15-18 July 2001; pp. 3.

7. Bigot M, Cuchet E. Mechanized harvesting system for hardwoods. In: M. Iwarsson Wide \& B. Baryd, editors. Arbetsrapport 537, SkogForsk. $2^{\text {nd }}$ Forest Engineering Conference, Växjö, Sweden. 12-15 May 2003; pp. 57-66.

8. Moscatelli M, Pettenella D, Spinelli R. Produttività e costi della lavorazione meccanizzata dei cedui di castagno in ambiente appennico (Productivity and costs of fully mechanised harvesting in Italian Appenines' chestnut coppices). Forest. 2007;4(1):51-9.

9. Spinelli R, Magagnoti N, Nati C. Options for the mechanised processing of hardwood trees in Mediterranean forests. Int J Forest Eng. 2009;20(1):39-44.

10. Spinelli R, Ward SM, Owende PM. A harvest and transport cost model for Eucalyptus spp. fast-growing short rotation plantations. Biomass Bioener. 2009;33:1265-70.

11. Danilović M, Tomašević I, Gačić D. Efficiency of John Deere 1470D ECOIII harvester in poplar plantations. Croat J For Eng. 2011;32(2):533-48.

12. Spinelli R, Magagnotti N, Nati C. Work quality and veneer value recovery of mechanised and manual log-making in Italian poplar plantations. Eur J For Res. 2011;130(5):737-44.

13. Price M. Use of accumulating and processing harvesting heads. FCJR079, Technical Development, Forest Research. 2012; pp. 30. https://www.forestresearch.gov.uk/documents/2001/FR BEC_Use_of_accumulating_and_processing_harvesting_heads_ FCJR079_2012.pdf (accessed on 15.01.2021).

14. Mederski PS, Werk K, Bembenek M, Karaszewski Z, Brunka M, Naparty K. Harvester efficiency in trunk utilisation and log quality of early thinning pine trees. For Res Pap. 2019;80(1):45-53. https://doi.org/10.2478/frp-2019-0004.

15. Mederski PS, Karaszewski Z, Rosińska M, Bembenek M. Dynamics of harvester fleet change in Poland and factors determining machine occurrence. Sylwan. 2016;160(10):795804. https://doi.org/10.26202/sylwan.2016030.

16. Malinen J, Laitila J, Väätäinen K, Viitamäki K. Variation in age, annual usage and resale price of cut-to-length machinery in different regions of Europe. Int J For Eng. 2016;27(2):95102. https://doi.org/10.1080/14942119.2016.1171964.

17. Moskalik T, Borz SA, Dvořák J, Ferencik M, Glushkov S, Muiste P, Styranivsky O. Timber harvesting methods in Eastern European countries: a review. Croat J For Eng. 2017;38(2):231-41

18.• Mederski PS, Borz SA, Đuka A, Lazdiņš A. Challenges in forestry and forest engineering - case studies from four countries in east Europe. Croat J For Eng. 2021;42(1):117-34. https:// doi.org/10.5552/crojfe.2021.838. (The paper describes forest resources and forest management in Croatia, Latvia, Poland and Romania, where the forest sector is important for the country's economy. Forest operations were presented in the paper, including the conditions challenging the wider use of cut-to-length technology. Soil conditions, steep terrain and a larger share of broadleaved species were found to be the main limiting factors.)

19. Mederski PS, Bembenek M, Karaszewski Z, Łacka A, Szczepańska-Álvarez A, Rosińska M. Estimating and modelling harvester productivity in pine stands of different ages, densities and thinning intensities. Croat J For Eng. 2016;37(1):27-36.

20. Buras A, Menzel A. Projecting tree species composition changes of European Forests for 2061-2090 under RCP 4.5 and RCP 8.5 scenarios. Front Plant Sci. 2019;9:1986. https://doi.org/10.3389/ fpls.2018.01986.

21.•• Coll L, Ameztegui A, Collet C, Löf M, Mason B, Pach M, Verheyen K, Abrudan I, Barbati A, Barreiro S, Bielak K, BravoOviedo A, Ferrari B, Govedar Z, Kulhavy J, Lazdina D, Metslaid M, Mohren F, Pereira M, Peric S, Rasztovits E, Short I, Spathelf P, Sterba H, Stojanovic D, Valsta L, Zlatanov T, Ponette Q. Knowledge gaps about mixed forests: What do European forest managers want to know and what answers can science provide? Forest Ecol Manag. 2018;407:106-15. https://doi.org/10.1016/j. foreco.2017.10.055. (The paper focuses on the main issues of management of mixed forests in Europe and is based on a survey of foresters. The key findings are that mixed forests are considered valuable and more resistant against natural calamities; however, less is known about what kind of forest management should be provided and which mixed forests are in fact the best solution for environmental benefits. Key challenging factors are presented in the paper as indications for future research.)

22.•• Picchio R, Mederski PS, Tavankar F. How and how much, do harvesting activities affect forest soil, regeneration and stands? Curr For Rep. 2020;6(2):115-28. https://doi.org/10.1007/ s40725-020-00113-8. (The paper includes a collection of recent studies on the impact of forest operations on the forest environment: soil, remaining stands and regeneration. It was demonstrated that cut-to-length technology has a limited (and the lowest) impact on the soil and the remaining stand.)

23. SEF 2020. State of Europe's Forests 2020. Ministerial Conference on the Protection of Forests in Europe - FOREST EUROPE. 2020; pp. 394. https://foresteurope.org/wp-content/ uploads/2016/08/SoEF_2020.pdf (accessed on 10.05.2021).

24. Jylhä P, Bergström D. Productivity of harvesting dense birch stands for bioenergy. Biomass Bioenerg. 2016;88:142-51. https://doi.org/10.1016/j.biombioe.2016.03.016.

25. Laitila J, Niemistö P, Väätäinen K. Productivity of multi-tree cutting in thinnings and clear cuttings of young downy birch (Betula pubescens) dominated stands in the integrated harvesting of pulpwood and energy wood. Balt For. 2016;22(1):116-31.

26. Zinkevicius R, Steponavicius D, Vitunskas D, Cinga G. Comparison of harvester and motor-manual logging in intermediate cuttings of deciduous stands. Turk J Agric For. 2012;36(5):591600. https://doi.org/10.3906/tar-1103-46.

27. Niemistö P, Korpunen H, Laurén A, Salomäki M, Uusitalo J. Impact and productivity of harvesting while retaining young understorey spruces in final cutting of downy birch (Betula pubescens). Silva Fenn. 2012;46(1):67. https://doi.org/10.14214/sf. 67.

28. Liepiņš K, Lazdiņš A, Liepiņš J, Prindulis U. Productivity and cost-effectiveness of mechanized and motor-manual harvesting of grey alder (Alnus incana (L.) Moench): a case study in Latvia. Small-Scale For. 2015;14(4):493-506.

29. CSB. Central Statistical Bureau Latvia. 2016. https://www. csb.gov.lv/en/statistics/statistics-by-theme/agriculture/fores try/search-in-theme/1997-forestry-costs-2015 (accessed on 04.07.2021).

30. Spinelli R, Cacot E, Mihelic M, Nestorovski L, Mederski P, Tolosana E. Techniques and productivity of coppice harvesting operations in Europe: a meta-analysis of available data. 
Ann For Sci. 2016;73:1125-39. https://doi.org/10.1007/ s13595-016-0578-x.

31. Oberer F. HSM in Frankreich (HSM in France). Wald Holz. 2019;1:19-22.

32. BMEL. Waldbericht der Bundesregierung 2017 (Forest Report of the Federal Government 2017) 2017; pp. 289. https://www.bmel. de/SharedDocs/Downloads/DE/Broschueren/Waldbericht2017. pdf?_blob $=$ publicationFile \&v $=3$ (accessed on 26.07.2021).

33. Schuldt B. Bodenschutz auf Rückegassen. Bundesweiter Überblick zum Einsatz von mechanisierten Holzernteverfahren in Laubholzbeständen (Soil protection on skid trails. Nationwide overview of the use of mechanised harvesting methods in hardwood stands). Bachelor thesis, Hochschule für Forstwirtschaft Rottenburg. 2014; pp. 92.

34. Mederski PS, Venanzi R, Bembenek M, Karaszewski Z, Rosińska M, Pilarek Z, Luchenti I, Surus M. Designing thinning operations in $2^{\text {nd }}$ age class pine stands - economic and environmental implications. Forests. 2018;9(6):335. https://doi. org/10.3390/f9060335.

35. Labelle ER, Windisch J, Gloning P. Productivity of a single-grip harvester in a beech dominated stand: a case-study under Bavarian conditions. J For Res. 2019;24(2):100-6. https://doi.org/10. 1080/13416979.2019.1566995.

36. Labelle ER, Breinig L, Sycheva E. Exploring the use of harvesters in large-diameter hardwood-dominated stands. Forests. 2018;9:424. https://doi.org/10.3390/f9070424. (This pilot study involved the monitoring of four harvesters operated in four distinct harvest blocks, all of which had a high percentage of large-diameter European beech and oak trees. Harvesting productivity ranged from 29 to $43 \mathrm{~m}^{3} \mathrm{PMH}_{0}{ }^{-1}$, whereas volume recovery fluctuated between 73 and $85 \%$ for trees that were completely felled and processed by machines. With increasing shares of deciduous trees being managed under mixed stands and close-to-nature forestry, the interest in using fully mechanised systems is expected to increase, which is the reason why this study is important for the further development and use of fully mechanised operations in hardwoods.)

37. Ruch P, Montagny X, Bouvet A, Ulrich E, George P. Mechanized processing of big broadleaved crowns an operational reality. In: A. Gendek, T. Moskalik, editors. 49th Symposium on Forest Mechanization (FORMEC): From Theory to Practice: Challenges for Forest Engineering. Warsaw, Poland, 4-7 September 2016; pp. 111-117.

38. Maire L, Bonnemazou M, Cacot E, Chakroun M, Peuch D, Montagny X. Le bûcheronnage mécanisé dans les peuplements feuillus: un secteur toujours en attente d'amélioration des performances (Mechanised logging in hardwood stands: a sector still awaiting improved performance). FCBA; 2016. pp. 7. https:// www.fcba.fr/ressources/fcba-info-le-bucheronnage-mecanisedans-les-peuplements-feuillus-un-secteur-en-attente-dameliorat ion-des-performances/ (accessed on 19.04.2021).

39. Bonnemazou M, Cacot E, Ruch P. Parc national d'engins forestiers et taux de mecanisation de la recolte forestiere en 2018 (Forest machinery and forest mechanisation rate in 2018). FCBA; 2019. pp. 3. https://www.fcba.fr/wp-content/ uploads/2020/11/fcbainfo-2019-12-parc-national-engins-fores tiers-taux-mecanisation-recolte-forestiere-2018-bonnemazoucacot-ruch.pdf (accessed 19.04.2021).

40. Boldrini C, Bonnemazou M, Peuch D, Perinot C, Cacot E. Machines de bucheronnage pour les feuillus etat des lieux du parc et emthodes travail (Inventory of logging machines for hardwoods and working methods). FCBA; 2018. pp. 5. https:// www.fcba.fr/wp-content/uploads/2020/09/Fcbainfo_2018_ 42_parc_machines_bucheronnage_feuillus.pdf (accessed 19.04.2021).
41. Suchomel C, Becker G, Pyttel P. Fully mechanized harvesting in aged oak coppice stands. Forest Prod J. 2011;61(4):290-6. https://doi.org/10.13073/0015-7473-61.4.290.

42. Spinelli R, Pari L, Aminti G, Magagnotti N, Giovannelli A. Mortality, re-sprouting vigor and physiology of coppice stumps after mechanized cutting. Ann For Sci. 2017;74:5. https://doi.org/10.1007/s13595-016-0604-z.

43. Schweier J, Spinelli R, Magagnotti N. Mechanized coppice harvesting with new smallscale feller-bunchers: results from harvesting trials with newly manufactured felling heads in Italy. Biomass Bioenerg. 2015;72:85-94. https://doi.org/10. 1016/j.biombioe.2014.11.013.

44. Chakroun M, Bouvet A, Ruch P, Montagny X. Performance of two shear heads for harvesting biomass in hardwood stands in France. Biomass Bioenerg. 2016;91:227-33.

45. Kleinschmit $\mathrm{C}$. The economically optimal processing intensity examined using the example of highly mechanised processing of beech crowns. Göttingen: Universitätsverlag Göttingen; 2015. pp. 159.

46. Cacot E, Fauroux JC, Peuch D, Bouvet A, Chakroun M. New delimbing tool for hardwood trees: feedback on new ribbed knives after one year experience. In: A. Gendek, T. Moskalik, editors. 49th Symposium on Forest Mechanization (FORMEC): From Theory to Practice: Challenges for Forest Engineering. Warsaw, Poland, 4-7 September 2016; pp. 37-43.

47. Schönauer H. BFW short film explaining harvester use for hardwoods. Original source: Press release of the Austrian Research Centre for Forests (BFZ), Vienna, 20 April 2016. Available online: https://www.waldwissen.net/de/technik-undplanung/forsttechnik-und-holzernte/forstmaschinen/harvestere insatz-fuer-laubwertholz (latest check 24 July 2021).

48. Hilberer S. Holzernte im Buchenwald (Timber harvesting in beech forest). Der Waldbauer. 2020; 3 (in German) https:// www.derwaldbauer.at/technik/2020/03/holzernte-im-buche nwald.html (accessed on 26.07.2021).

49. Bodył M. Share of mechanised timber harvesting in Poland (Rozmiar pozyskania maszynowego w Polsce). Drwal. 2019;3(166):5-9.

50. Dvořák J, Löwe R, Natov P, Jankovský M, Sedmíková M. Unrecorded volume of Norway spruce timber in cut-to-length harvesting. Scand J For Res. 2020;35(7):383-93. https://doi. org/10.1080/02827581.2020.1815829.

51. Mederski PS. The potential of harvester use for thinning operations in mixed birch-pine stands. University Press of Poznań University of Life Sciences. 2013; pp. 109.

52.•• Rosińska M, Bembenek M, Picchio R, Karaszewski Z, Đuka A, Mederski PS. Determining harvester productivity curves of thinning operations in birch stands of Central Europe. Croat J For Eng. 2022;43(1):1-12. https://doi.org/10.5552/crojfe. 2022.1691. (The aim of this study was to determine productivity curves when harvesting birch in thinning operations carried out by nine harvesters in 16 different stands in North Poland. Average productivity was $21.98 \mathrm{~m}^{3} \mathrm{PMH}_{0}$ and values ranged from $5.14 \mathrm{~m}^{3} \mathrm{PMH}_{0}$ to a maximum of $44.66 \mathrm{~m}^{3} \mathrm{PMH}_{0}$, which depended mainly on harvested tree size. The top diameter of the last log depended on tree size-the thicker the tree the larger the tree top remaining as not processed. The study confirmed limitations in harvester use in birch stands.)

53. Mederski PS, Bembenek M, Karaszewski Z, Rosińska M, Pilarek Z, Łacka A. Investigation of log length accuracy and harvester efficiency in processing of oak trees. Croat J For Eng. 2018;39(2):173-81.

54. Karaszewski Z, Łacka A, Mederski PS, Noskowiak A, Bembenek M. Damage caused by harvester head feed rollers to 
alder, pine and spruce. Drewno. 2016;59(197):77-88. https:// doi.org/10.12841/wood.1644-3985.C36.08.

55. Karaszewski Z, Łacka A, Bembenek M, Mederski PS. Wood damage and value loss of alder plywood harvested by Valmet 911.4 harvester with a 360.2 head. Sylwan. 2016;160(12):1002-9.

56. Bembenek M, Mederski PS, Karaszewski Z, Łacka A, Grzywiński W, Węgiel A, Giefing DF, Erler J. Length accuracy of logs from birch and aspen harvested in thinning operations. Turk J Agric For. 2015;39:845-50. https://doi.org/10. 3906/tar-1406-39.

57.• Magagnotti N, Spinelli R, Kärhä K, Mederski PS. Multi-tree cut-to-length harvesting of short-rotation poplar plantations. Eur J For Res. 2021;140(2):345-54. https://doi.org/10.1007/ s10342-020-01335-y. (This study involved harvester use in short-rotation poplar harvesting with the harvester head having an option (built-in software) for multi-stem cumulation and processing. The results show that the multi-stem option can give $8 \%$ higher productivity. Harvesting costs below $€ 15$ per green tonne were achieved, as well as satisfactory timber quality factors in terms of value recovery and $\log$ quality requirements.)

58. Mederski PS, Bembenek M, Erler J, Giefing DF. Effects of innovative thinning operation in a birch stand. Acta Sci Pol, Silv Colendar Rat Ind Lignar. 2011;10(4):29-38.

59. Mederski PS, Bembenek M, Karaszewski Z, Rosińska M. Potential of harvesters' use for broadleaved tree species. Final report: Poznań University of Life Sciences; 2016. p. 57.

60. Wang C. Potential of thinning operation with harvester in an oak-pine mixed stand. Master's thesis, Poznań University of Life Sciences. 2013; pp. 55.

$61 . \bullet$ Knobloch C, Erler J, Kurde S, Kurde M, Bembenek M, Mederski PS. Harvester head for hardwood (Harvesterkopf für Laubholz). 2021; Patent Number(s): DE102016114579, European Patent Office. (Patent presents new solutions for a harvester head that is dedicated to broadleaved species.)

62. Pettenella D, Klöhn S, Brun F, Carbone F, Venzi F. Italy’s Country Report. COST Action E30: Economic integration of urban consumers' demand and rural forestry production., 2005; pp. 49. 10.1007/3-540-26722-0_14.

63. Nabuurs G-J, Verweij P, Van Eupen M, Pérez-Soba M, Pülzl H, Hendriks K. Next-generation information to support a sustainable course for European forests. Nat Sustain. 2019;2(9):815-8.

64. Laina R, Tolosana E, Ambrosio Y. Productivity and cost of biomass harvesting for energy production in coppice natural stands of Quercus Pyrenaica Willd. in central Spain. Biomass Bioenerg. 2013;56:221-9. https://doi.org/10.1016/j.biombioe. 2013.04.016.

65. Nordfjell T, Björheden R, Thor M, Wästerlund I. Changes in technical performance, mechanical availability and prices of machines used in forest operations in Sweden from 1985 to 2010. Scand J For Res. 2010;25(4):382-9.

66. Picchio R, Tavankar F, Bonyad A, Mederski PS, Venanzi $\mathrm{V}$, Nikooy M. Detailed analysis of residual stand damage due to winching on steep terrains. Small-Scale For. 2019; 18:255277. https://doi.org/10.1007/s11842-019-09417-5

67. Spinelli R, Magagnotti N, Visser R, O'Neal B. A Survey of the skidder fleet of central, eastern and southern Europe. Eur J For Res. 2021;1-11. https://doi.org/10.1007/s10342-021-01374-z

68. Niskanen A, Pettenella D, Slee B. Barriers and opportunities for the development of small-scale forest enterprises in Europe. Small-Scale For. 2007;6(4):331-45.

69. Magagnotti N, Pari L, Spinelli R. Use, utilization, productivity and fuel consumption of purpose-built and excavator-based harvesters and processors in Italy. Forests. 2017; 8(12). https://doi. org/10.3390/f8120485. (This paper examines the differences between purpose-built and excavator-based harvesters and is of large practical importance by helping decision making of forest entrepreneurs. Productivity was lower for excavatorbased machines, and purpose-built harvesters presented higher annual utilisation, productivity and fuel efficiency in comparison to excavator-based machines. Excavator-based machines had 2.4 times higher fuel consumption compared with purpose-built machines.)

70. Spinelli R, Magagnotti N, Picchi G. Deploying mechanized cutto-length technology in Italy: fleet size, annual usage, and costs. Int J For Eng. 2010;21(2):23-31.

71. Magagnotti N, Nati C, Picchi G, Spinelli R. Mechanized thinning of walnut plantations established on ex-arable land. Agrofor Syst. 2011;82(1):77-86.

72. Magagnotti N, Pari L, Picchi G, Spinelli R. Energy biomass from the low-investment fully mechanized thinning of hardwood plantations. Biomass Bioenerg. 2012;47:195-200. https://doi. org/10.1016/j.biombioe.2012.09.042.

73. Spinelli R, Magagnotti N, Di Fulvio F, Bergström D, Danelon M, Alberti G. Comparison of cost efficiency of mechanized fuel wood thinning systems for hardwood plantations on farmland. Croat J For Eng. 2014;35(2):111-23.

74. Suchomel C, Spinelli R, Magagnotti N. Productivity of processing hardwood from coppice forests. Croat J For Eng. 2012;33(1):39-47.

75. Tavankar F, Nikooy M, Latterini F, Venanzi R, Bianchini L, Picchio R. The effects of soil moisture on harvesting operations in Populus spp. plantations: specific focus on costs, energy balance and GHG emissions. Sustainability. 2021;13(9). https://doi.org/ 10.3390/su13094863.

76. Ferrari E, Spinelli R, Cavallo E, Magagnotti N. Attitudes towards mechanized cut-to-length technology among logging contractors in northern Italy. Scand J For Res. 2012;27(8):800-6. https://doi. org/10.1080/02827581.2012.693192.

77. Bončina A, Čavlović J. Perspectives of forest management planning: Slovenian and Croatian experience. Croat J For Eng. 2009;30(1):77-87.

78. Matović B, Koprivica M, Kisin B, Stojanović D, Kneginjić I, Stjepanović S. Comparison of stand structure in managed and virgin European beech forests in Serbia. Šumarski list. 2018;142(1-2):47-57.

79. Trajkov P, Dubravac T, Tanovski V, Nestorovski L, Sotirovski $\mathrm{K}$, Trajanov Z. Coppice forest management planning and the regeneration potential of pure and mixed oak coppice forests in North Macedonia. SEEFOR. 2019;10(2):165-72.

80. Ganatsios HP, Tsioras PA, Papaioannou AG, Blinn CR. Short term impacts of harvesting operations on soil properties in a Mediterranean oak ecosystem. Croat J For Eng. 2021;42(3). Early-view paper. https://doi.org/10.5552/crojfe.2021.1100.

81. Đuka A, Bumber Z, Poršinsky T, Papa I, Pentek T. The influence of increased salvage felling on forwarding distance and the removal - a case study from Croatia. Forests. 2021;12(1):7. https://doi.org/10.3390/f12010007.

82. Poje A, Potočnik I. Influence of working conditions on overlapping of cutting and ground skidding in group work. Croat J For Eng. 2007;28(2):157-67.

83. Kranjec J, Poršinsky T. History of chainsaw development. Nova Mehanizacija Šumarstva. 2011;32:23-37.

84. Koutsianitis D, Tsioras PA. Time consumption and production costs of two small-scale wood harvesting systems in northern Greece. Small-Scale For. 2017;16(1):19-35.

85. Pičman D, Pentek T, Nevečerel H, Papa I, Lepoglavec K. Possibilities of application of relative openness in secondary forest opening of slope forests in Croatia. Croat J For Eng. 2011;32(1):417-27. 
86. Jeličić V. Šumske ceste i putevi (Forest roads and trails). SIZ odgoja i usmjerenog obrazovanja šumarstva i drvne industrije SRH. 1983; Zagreb; pp.193 (in Croatian).

87. Krč J, Vranešič U, Košir B. Comparison of mechanized and motor-manual cutting operation in mixed stands of southern Slovenia. Šumarski List. 2015;139(7-8):351-9.

88. Vusić D, Rukavina N. Influence of black pine tree's forkness on harvester's productivity. Nova mehanizacija šumarstva. 2010;31:37-43.

89. Krpan AP, Poršinsky T. Harvester Timberjack 1070 in Croatia. Šumarski List. 2001;125(11-12):619-24.

90. Beguš J, Krč, J. Ways in introducing modern technologies in Slovenian forests with the emphasis on logging by harvester and forwarder. In: Croatia 2012 Proceedings. 45th Symposium on Forest Mechanization (FORMEC): Forest engineering: Concern, Knowledge and Accountability in Today's Enviroment. Dubrovnik (Cavtat), Croatia, 8-12 October 2012; pp. 1-10.

91. Krč J. Assessment of mechanized cutting operations in the Slovenian state forests. In: Italy 2010 Proceedings. 43th Symposium on Forest Mechanization (FORMEC): Forest Engineering: Meeting the Needs of the Society and the Environment. Padova, Italy, 11-14 July 2010; pp. 1-11.

92. Marčeta D, Petković V. Istraživanje različitih tehnologija sječe u završnim sječama u plantažama četinara (Research on different harvesting technologies in coniferous plantations). International conference "Šumsko inženjerstvo Jugoistočne Evrope - stanje i izazovi", 28-30 October 2015. Goč, Srbija. In: https://www.slide share.net/DusanStojnic/mareta-et-al-istraivanje-razliitih-tehno logija-sjee-u-zavrnim-sjeama-u-plantaama-etinara (accessed on 25.03.2021).

93. Krpan AP, Poršinsky T. Efficiency of mechanical felling and processing in soft and hardwood broadleaved stands - Part 2: Efficiency of harvesters in the culture of soft broadleaf trees. Šumarski List. 2004;128(5-6):233-44.

94. Krpan AP, Poršinsky T, Stankić I. Efficiency of mechanical felling and processing in soft and hardwood broadleaved stands; Part 3: Efficiency of harvester in natural thinning stands of hardwood broadleaf species. Šumarski List. 2004;128(9-10):495-508.
95. Vusić D, Plantak M, Papa I, Đuka A, Pentek T, Poršinsky T. Analysing the efficiency of mechanised thinning in broadleaf stands. In: Spain 2018 Proceedings. 41st Symposium on Forest Mechanization (FORMEC): Improved Forest Mechanisation: Mobilizing natural resources and preventing wildfires. Madrid, Spain, 24-28 September 2018; pp. 362-363.

96. Beguš, J. Razvoj in stanje rabe strojne sečnje v Sloveniji (State and development of mechanised felling in Slovenia). Vpliv gozdarskih tehnologij na gozdna tla, 18 October 2018, Pokljuka, Slovenia. In: https://www.alpine-space.eu/projects/links4soils/ projectresults/capacity-building-trainings/slovenia-forest-servi ce/begus.pdf. Accessed 10 April 2021.

97. Marčeta D, Petković V, Ljubojević D, Potočnik I. Harvesting system suitability as decision support in selection cutting forest management in Northwest Bosnia and Herzegovina. Croat J For Eng. 2020;41(2):1-17.

98. Triplat M, Krajnc N. Assessment of costs in harvesting systems using wood chain manager web-based tool. Croat J For Eng. 2020;41(1):48-57. https://doi.org/10.5552/crojfe.2020.583.

99.•• Spinelli R, Magagnotti N, Labelle ER. The effect of new silvicultural trends on mental workload of harvester operators. Croat J For Eng. 2020;41(2):1-13. https://doi.org/10.5552/crojfe.2020. 747. (This paper gives insight into the mental workload of harvester operators under two silvicultural regimes: a pure conifer stand and a mixed stand. The study confirmed the intensification of mental demand, effort and frustration experienced by the operators when changing from the pure conifer stand to the mixed stand. Additionally, work in the mixed stand resulted in productivity loss, estimated between 40 and $57 \%$. Interesting, such an increase in the mental workload was independent of the age and experience of the operators. Since it is expected that harvesters will be used more and more in broadleaved stands, results of this study could be used to show a more holistic approach of close-to-nature forestry and its future implications for harvester operators.)

Publisher's Note Springer Nature remains neutral with regard to jurisdictional claims in published maps and institutional affiliations. 